\title{
Development of Historical Learning Media Based on Documentary Film to Strengthen Student's Understanding of Local History
}

\author{
Elis Setiawati ${ }^{1}$, Bobi Hidayat ${ }^{1}$, Umi Hartati ${ }^{1}$, Anggi Widiastuti ${ }^{1}$ \\ ${ }^{1}$ History Education Program, Faculty of Teacher Training and Education, University of Muhammadiyah Metro, \\ Indonesia
}

Corresponding Author: Elis Setiawati

\begin{abstract}
One of the goals of learning history is in addition to fostering historical awareness; it also introduces the concept of collective identity in students. Awareness of identity is very important for the life of the nation and state amidst the strengthening of globalization. Strengthening awareness of collective identity through historical education can use a local historical approach that contains local identities. Local history has a more contextual position from the student's point of view because it is closer to and around students. So that strengthening the understanding of local history is the initial stage that must be taken. Therefore, the use of historical learning media that utilizes local history material in schools is important. This study uses the first level Research and Development method, with a focus on designing learning product designs. The results showed that the design of learning media for historical documentary films with the material of the Implementation of Ethical Policies through Colonization Policies in Metro Lampung was by the core competencies and basic competencies in the 2013 Curriculum. The results of validation by stage 1 material experts were $59.3 \%$ with the criteria "Eligible", the second stage material expert was $93.3 \%$ with the criteria "Very Appropriate", while the results of the validation of the 1st stage design expert were $76.6 \%$ with the "Proper" criteria, the 2nd stage design expert was $88.6 \%$ with the criteria "Very Feasible". The results of the responses of students to the design of learning media were $88.4 \%$ (Very Feasible). It was concluded that the learning media in the form of a historical
\end{abstract}

documentary film with the material of Ethical Policy Implementation through Colonization Policy in Metro Lampung deserves to be tested as a historical learning medium to strengthen students' understanding of local history in high schools.

Keywords: Instructional Media, Documentary Films, Historical Understanding, Local History

\section{INTRODUCTION}

Indonesia is now entering an era of disruption in world globalization. An era of uncertainty that demands every nation to continue to struggle to maintain its existence amid an increasingly uniform world culture. National identity is becoming increasingly important to be fought for. History is one of the keys to recognizing identity and finding self-identity, society, nation, and state. National identity can be found in the history of nationality, while social identity can be found through the history of the society itself. So that national history and local history will complement each other. Given the importance of learning local history, of course, understanding the history that is around students is very important because knowledge of localization can be useful as an identity amid globalization or the expansion of global culture that will obscure unique and distinctive identities.

Local history is a history that is very close to students, it is closely related to identity. By studying local history, students will be invited to recognize and deepen their 
collective identity as part of society. Local historical information is stored as a form of memory in historical stories, local wisdom, and historical remains. These legacies are traces of predecessors who shaped and created the current state. In this regard, Lampung in the past was an area that had a long historical journey. Among them were when Lampung was made the location for the implementation of Ethical Policies in the early twentieth century, as the location for the placement of colonization policies or the relocation of people from Java to outside Java in 1905. Policies as part of this van de Venter Trilogy (Education, Irrigation, and Migration), especially migration which later became known as colonization, was carried out in several waves from 1905 to 1942, and the Metro area was one of the areas that emerged and developed due to the implementation of this colonization. In historical records, Metro, which was the capital of the Sukadana Colonization, was considered as an example of the success of the colonization program implemented by the colonial government. Until now, there are many historical heritages, both material and intangible, that exist today (Amboro, 2021; Amboro et al., 2018; Amboro \& Bambang, 2020; Kuswono et al., 2020). However, the existence of this local history has not been fully utilized by the community, also in the context of education. Even though these local historical events can be a reminder and reinforcement of community identity because they explain how a community originated, grew, and developed until it is today.

History has an important role in recognizing one's identity, society, nation, figures, and heroes in every area of life. It is so important that history is a fundamental knowledge that has an important role in shaping students' identity, character, and mindset. Through the process of learning history, a nation will increasingly understand its identity, because history will explain its origins or background. Through history, humans will know the actions, thoughts, and struggles of humans to reveal their fate in the past. History will support the foundation for the personality of a nation in the form of conditions that are provided and passed on by my experience (Samat, 2021). The process of forming personality and identity will run if students can think historically which grows and develops from their history learning process (Fadli et al., 2020), as well as taking values from every history and whatever is left by the past to become a character. which can be developed (Amboro \& Anindita, 2020).

One of the educational institutions in Metro that has fairly good educational institution qualifications is SMA Kartikatama Metro, which is one of the private schools in Metro City. The availability of learning facilities and infrastructure is good enough for this school, including learning technology facilities. However, the learning history has not yet optimized the existence of local history, local events, sources, and learning media relating to the local context which are very close to the students. The learning that has been carried out so far is very rigid and fixated on the national curriculum, namely the 2013 Curriculum. Even though the 2013 curriculum itself provides space for every teacher to explore all the potential that exists around students to be used in learning activities, both as a source of learning and learning media.

Asyhar revealed that learning media is anything that can convey or transmit messages from a source in a planned manner, resulting in a conducive learning environment where the recipient can carry out the learning process efficiently (Asyhar, 2011). In this study, the learning media developed based on the existing potential is in the form of historical documentary film media. Apart from its advantages as an audio-visual media that can help students understand learning material, develop historical imagination skills, it also helps students to be motivated in learning history even though in distance learning due to the Covid-19 pandemic situation. Several previous studies have shown that the use of 
instructional media according to needs has a positive impact on the optimal achievement of learning objectives (Afifah \& Hidayat, 2019; Agustina \& Amboro, 2018; Ernasari \& Amboro, 2017; Hartati, 2016; Rafika \& Amboro, 2018).

One type of learning media that is attractive to students is the type of audiovisual learning media. Audiovisual media is a combination of images, sound, and video. Where the three types are combined into a complete unit that can be enjoyed by the audience. Audiovisual media can convey information or understanding more concretely and interestingly in a way that can be felt in real terms compared to what is conveyed through spoken or written words.

A historical documentary film is a form of audio-visual learning media. Based on its definition, documentary films are programs that present a reality based on objective factors that have essential and existential values that are relevant to life, tell facts, and reality without engineering (Rikarno, 2015). The documentary film is a medium that displays moving objects/images with sound effects (audiovisual), are made based on facts and describes a situation or reality, and does not contain elements of a scenario (Susanto et al., 2021). Based on this definition, documentary films are very by the characteristics of historical science which prioritizes the truth of events based on facts and authentic evidence, as stated by Hayward that documentary films are a creative way to represent reality (Utami, 2010). So that documentary films are very appropriate when used as a medium for learning history.

Several previous studies regarding documentary films show that the use of documentary films in the learning process has a good influence on the achievement of learning objectives, both in the form of critical thinking skills, preservation of traditions, to digital historiography alternatives (Ratmanto, 2018; Rikarno, 2015; Susanto et al., 2021; Utami, 2010). The accuracy of using documentary films as a medium for learning history can be seen that history learning is learning that presents important events that occurred in the past so that using historical documentary film media will greatly help students learn to construct their knowledge of the past.

\section{RESEARCH METHODS}

The research method used in developing learning media is a development model adapted from Sugiyono level one research (Sugiyono, 2015). This research was conducted at SMA Kartikatama Metro with the following research steps:

Potential and problem analysis. This research begins with a potential and problem analysis. Potential is everything if it is utilized to have added value so that it is known the development of learning media needed in the field. After conducting observations, interviews with teachers and students at SMA Kartikatama Metro, there were problems in learning, namely the unavailability of unique, creative, and contextualizing learning media for local history material in schools.

Study of literature. After the potential and problems are found, then it is necessary to collect various information that can be used as material for planning certain products that are expected to overcome these problems. Literature studies are carried out to find a theoretical basis and the results of previous studies that have been carried out to be considered as material for considering the design of instructional media to be developed. The results of the literature review in this study focus on learning media theories, types of instructional media, documentary films, local history, especially the material on the Implementation of Ethical Policies, namely Colonization in Metro Lampung and previous studies that examine the problems of developing learning media, documentary films, and contextualization of local history in Indonesian history subjects.

Product Design. The product design in question is the initial product design that will be validated, the results of potential and 
problem analysis, and information gathering. The product design to be developed in this study is a historical documentary film that uses the learning material for the Implementation of Ethical Policy, namely Colonization in Metro Lampung. The result of this stage is the preparation of the initial product design, which is ready to go through the validation test phase in several stages. The design stage begins with preparing the material obtained based on the results of a literature study, compiling a documentary film script, recording sources, and the film editing process.

Product design validation. Design validation is an activation process to assess whether the product design is feasible or not. The validators or experts to validate this historical documentary film media, namely lecturers from Muhammadiyah Metro University as material experts and film editor practitioners as design experts, as well as class XI students at SMA Kartikatama Metro who gave responses as users.

\section{Product Design Improvement.} After going through the product design validation stage, it will be known what the strengths and weaknesses are. The next step is to improve the design to complete the shortcomings and ask for corrections to matters relating to the appearance and appropriateness of the learning media presented. The results of this revision are expected to formulate a learning media for historical documentary films on the material of Ethical Policy Implementation, namely Colonization in Metro Lampung, especially in class XI at Kartikatama Metro. The product design improvement stage is declared complete if it meets certain criteria, namely if the product draft has been declared feasible and is ready by the validator to be tested in the field.

RESULTS AND DISCUSSION Utilization of History Learning Media at Kartikatama Metro High School
Based on interviews and observations conducted on August 31, 2020, it was found that the learning media facilities at SMA Kartikatama Metro were quite complete. Including the existence of internet facilities. In the process of learning history, teachers not only make use of subject textbooks, but also use other historical learning media such as maps, globes, presentation media such as LCD projectors, and even use multimedia rooms.

However, when observations and interviews were carried out, the learning process took place online because it was still in the Covid-19 pandemic situation, through a distance learning approach, so that the various learning media available in schools and classrooms could not be used. Based on the results of interviews with teachers and students, information was obtained that local historical materials had not been taught. The absence of learning resources and learning media that can be used is the root of the problem. The teacher said that they still have limited knowledge about local history, especially the history of Metro City, the area where students live and even go to school. The existence of the existing learning media does not contain information about local history materials. Most of it is just general history and Indonesian history.

\section{Analysis of the Needs of Teachers and Students in Learning History at SMA Kartikatama Metro}

Starting from the unavailability of historical instructional media that relates to local historical events, the learning media currently needed by teachers are those that contain local historical content. The results of observations made by researchers indicate that the teacher has prepared learning strategies that can facilitate the use of local historical content. However, the existence of available learning media is limited to textbook modules that generally do not link, contextualize with local history or local historical events that exist around students. Whereas historical learning about 
local knowledge that is around students is very important, and educators need to teach it to their students through contextual approaches both progressively and regressively (Amboro, 2019; Barton \& Levstik, 2008; Booth, 2003; Kyvig \& Marty, 2010). Teaching local history will open students' understanding of history more concretely and become an initial means of building affective aspects that are relevant to history (Amboro, 2013, 2015). Utilizing local history that exists around students, will make it easier for students to find historical significance as part of historical thinking skills that need to be built from historical education both formally and informally (Amboro, 2020; Clark \& Levesque, 2018; Levesque, 2008).

Based on the results of the needs analysis, it can be concluded that the teachers and students of Class X SMA Kartikatama Metro need learning media that can be used in distance learning through technical assistance. The existence of learning media in the form of historical documentary films containing local history material can be the right step to optimize the achievement of history learning objectives during a pandemic.

\section{Historical Documentary Film Design Developed}

Based on the results of the needs analysis which illustrates the conditions in the field that require learning media that can be developed for student learning according to their needs, the researcher will develop a historical documentary film media specifically discussing the Implementation of Ethical Politics through Colonization Policy in Metro Lampung. This is done by adjusting Core Competencies and Basic Competencies to link the material to be developed. In preparing the development of documentary film media, there are several aspects to consider, including: (1) aspects of material feasibility, (2) presentation aspects, (3) feasibility of linguistic aspects, (4) appraisal feasibility of historical documentary films for historical learning,
(5) appearance comprehensive historical documentaries such as editing, sound layout, image layout, and narration.
After determining
Core Competencies, Basic Competencies, determining indicators and materials that are by the 2013 Curriculum, the next step is to collect data related to the material on the Implementation of Ethical Policies through Colonization Policy in Metro Lampung. After the material is arranged, the next step is to draft a historical documentary film product, determine the informants and resource persons, make the documentary film narrative flow, and match the material that has been collected. The product of this development is in the form of a historical documentary in which it tells about the implementation of colonization in Metro as the beginning of the formation of Metro City.

A documentary film is a medium that displays moving objects/ images with sound effects (audiovisual), are made based on facts and describes a situation or reality, and does not contain elements of a scenario (Susanto et al., 2021). Based on this definition, documentary films are very by the characteristics of historical science which prioritizes the truth of events based on facts and authentic evidence, as stated by Hayward that documentary films are a creative way to represent reality (Utami, 2010). So that documentary films are very appropriate when used as a medium for learning history.

After the flow of the preparation of the historical documentary film is complete, the next stage is validating the material and validating the design. The feasibility test of a historical documentary film developed based on the judgment of an expert, in determining the validator, there must be a consideration in his ability to assess the product that the researcher has developed, namely a historical documentary film. The assessment carried out by this validator also contained suggestions and comments from the validator team. 
Elis Setiawati et.al. Development of historical learning media based on documentary film to strengthen student's understanding of local history.

\section{Product Validation Data Presentation}

The Historical Documentary Film that has been developed will then be validated by a team consisting of three design experts who assess aspects of editing, sound, images, layout, and narrative. Furthermore, three material experts assessed historical documentary films in presenting the material, language, and then collect responses from class XI students of SMA Kartikatama Metro as users.

This stage is an activity in which to assess the rationale for product design carried out by experts. Each validator and student will fill out a questionnaire sheet that has been given by the researcher by marking a checklist $(\sqrt{ })$ in the column that corresponds to the existing assessment aspect or indicator.

\section{Validation Test for Historical Documentary Films}

Based on the data obtained on the validation of learning media carried out by three material expert validators, the aspect being assessed is the feasibility of the material. In the first stage of validation, the assessment results were obtained with an eligibility percentage of $59.3 \%$ with the criteria "Enough". Meanwhile, in the second stage of validation obtained the percentage of feasibility is $93.3 \%$ with the criteria "Very Appropriate". The results of validation carried out by material experts between stage 1 and stage 2 increased by $34 \%$. The following is an illustration of the results of validation by material experts in stage 1 and stage 2 , which are as follows:

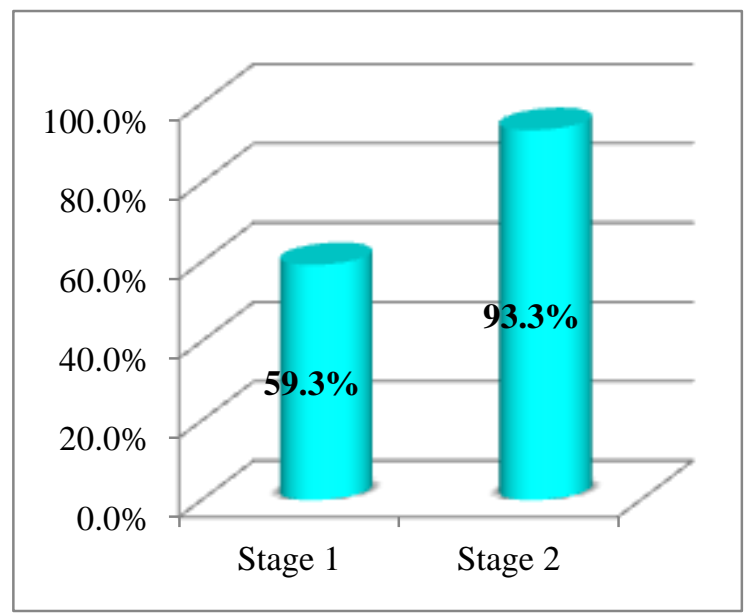

Figure 1.The results of the material validation assessment in stages 1 and 2

Based on the data above, it can be concluded that the historical documentary film has met the material feasibility to be tested.

Meanwhile, at the design validation test stage, there is a comparison of the results of the design validation test stage 1 and stage 2. In the design validation test stage 1 , the percentage of the design validation of a historical documentary film is obtained by $76.6 \%$ with the criteria "feasible". Furthermore, the design validation test stage 2 obtained a percentage of $88.6 \%$ with the criteria "Very Appropriate". The following is an illustration of the percentage of the results of the historical documentary film design validation test results in stages 1 and 2 .

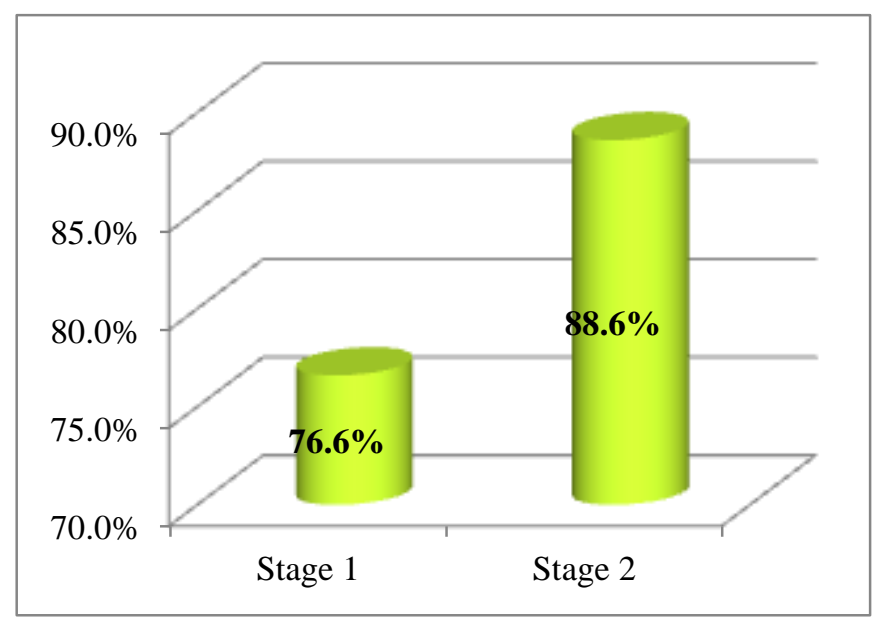

Figure 2.The results of the design validation assessment at stages 1 and 2 
Based on the data from the validation test results above, it can be concluded that the learning media in the form of historical documentary films that have been developed have met the requirements and several criteria at the validation test stages 1 and 2 . The historical documentary film media that have been declared feasible to be tested for history learning in class XI can be tested. become one of the references for historical learning media that can provide insight in linking local historical material. To see a clearer picture regarding the results of validation by design and material experts, the following are the responses by class XI students of SMA Kartikatama Metro by getting a percentage of $88.4 \%$ with the criteria "Very Good" as follows:

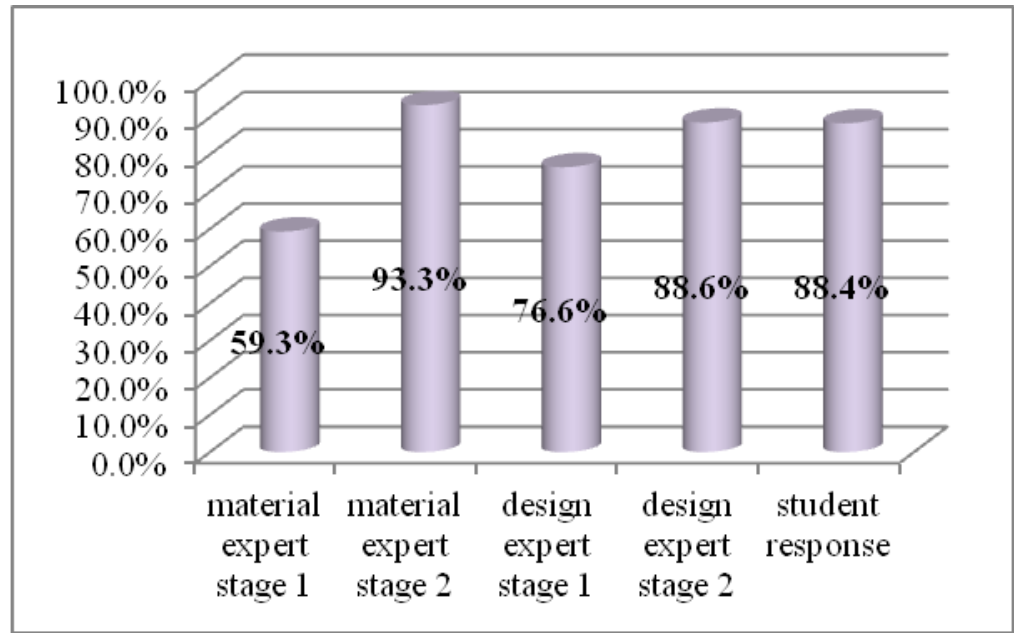

Figure 3. The results of the percentage of material and design validation assessments, historical documentary film media at stages 1 and 2 , as well as student responses to the draft historical documentary film products.

Based on the data above, it can be concluded that the draft of the development product in the form of a historical documentary film has met the feasibility of the material and design, as well as positive responses from students to be recommended to enter the next stage, namely the testing phase.

\section{Strengths and Weaknesses of the Developed Historical Documentary Film Media}

Based on the results of the development of learning media products in the form of Historical Documentary Films with learning materials on the Implementation of Ethical Policies through Colonization Policies in Metro Lampung, it can be identified that the advantages of the product drafts that are ready and worthy of being tested are as follows:

1. Historical documentary film media with material on the Implementation of Ethical Policy through Colonization
Policy in Metro Lampung can be a reference for learning media that is creative, innovative, and has local historical content can help students to better understand historical events that have occurred in the immediate environment and around them.

2. The presentation of learning media in the form of audio visuals can make history learning more interesting so that it can increase student learning motivation.

3. The learning media in the form of this historical documentary film has been developed based on certain criteria and aspects which are the requirements for a good learning media so that it can be used by all ages.

Whereas those that are still lacking in learning media products in the form of historical documentaries with learning material on the Implementation of Ethical 
Politics through Colonization Policy in Metro Lampung are as follows:

1. The learning media for this historical documentary film has limited scope, namely only on the material of the Implementation of Ethical Politics through Colonization Policy in Metro Lampung, and is local. The limited scope of this material certainly does not describe or represent similar events that occur in different places even though there are similarities in the timing of the events.

2. The products developed from this research are highly dependent on audiovisual media player devices, such as laptops, computers, smartphones, so they cannot be used in all classes and learning places.

3. This research is a level I development research, so there is no result of the effectiveness of the product after being tested.

\section{CONCLUSION \\ Conclusion}

Historical Documentary Film Media with learning material on the Implementation of Ethical Politics through Colonization Policy in Metro Lampung has been declared valid/worthy from the assessment of the validator team. This is based on the results of the validation by the first stage material expert of $59.3 \%$ with the criteria of "Eligible", the stage 2 material expert of $93.3 \%$ with the criteria of "Very Appropriate", while the results of the validation of the stage 1 design expert were $76.6 \%$ with the criteria "feasible", design experts stage 2 amounted to $88.6 \%$ with the criteria "very feasible", and student responses obtained a percentage of $88.4 \%$ with the criteria "very feasible".

\section{Suggestion}

The suggestion from the first researcher is to continue this research to the next stage, namely testing, to determine its effectiveness in learning. The second suggestion is to deepen the material because much of the local history material in Metro City has not been deepened and used as material for local history learning. Then make developments in both teaching materials, media, or worksheets with different local history materials in Indonesia to improve the quality of education, especially history learning

\section{Acknowledgement: None}

\section{Conflict of Interest: None}

\section{Source of Funding: None}

\section{REFERENCES}

1. Afifah, N., \& Hidayat, B. (2019). Pengembangan Media Pembelajaran Berbasis Videoscribe pada Materi Sejarah Kerajaan Islam di Sumatra dan Akulturasinya Kelas $\mathrm{X}$ SMA Muhammadiyah 1 Metro. SWARNADWIPA: Jurnal Kajian Sejarah, Sosial, Budaya, Dan Pembelajarannya, 2(3). https://www.ojs.ummetro.ac.id/index.php/s warnadwipa/article/download/889/650

2. Agustina, D., \& Amboro, K. (2018). Pengembangan Desain Media Pembelajaran Berbasis Katalog Peninggalan Sejarah Lokal Untuk Menguatkan Pemahaman Sejarah Lokal Siswa di SMA Negeri 3 Menggala Tulang Bawang. SWARNADWIPA: Jurnal Kajian Sejarah, Sosial, Budaya, Dan Pembeajarannya, 2(3), 165-178. http://www.ojs.ummetro.ac.id/index.php/sw arnadwipa/article/view/886

3. Amboro, K. (2013). Hubungan Antara Pemahaman Sejarah Nasional Indonesia dan Sikap Nasionalisme dengan Kesadaran Sejarah Mahasiswa Program Studi Pendidikan Sejarah FKIP Universitas Muhammadiyah Metro Tahun Akademik 2013/2014. Universitas Sebelas Maret.

4. Amboro, K. (2015). Membangun Kesadaran Berawal Dari Pemahaman; Relasi Pemahaman Sejarah Dengan Kesadaran Sejarah Mahasiswa Program Studi Pendidikan Sejarah Fkip Universitas Muhammadiyah Metro. Historia: Jurnal Program Studi Pendidikan Sejarah, 3(2), 109. https://doi.org/10.24127/hj.v3i2.150

5. Amboro, K. (2019). Kontekstualisasi Pandemi Covid-19 dalam Pembelajaran 
Sejarah. Yupa: Historical Studies Journal, $3(2)$, 90-106. https://doi.org/10.30872/yupa.v3i2.203

6. Amboro, K. (2020). Sejarah Publik dan Pendidikan Sejarah Bagi Masyarakat. Jurnal Historis: Jurnal Kajian, Penelitian \& Pengembangan Pendidikan Sejarah, 5(1), 29-40.

https://doi.org/https://doi.org/10.31764/histo ris.v5i1.2420

7. Amboro, K. (2021). Bendung Argoguruh 1935 dan Potensinya sebagai Sumber Pembelajaran Sejarah di Lampung. MUKADIMAH: Jurnal Pendidikan, Sejarah, Dan Ilmu-Ilmu Sosial, 5(1), 100110.

8. Amboro, K., \& Anindita, I. P. (2020). Urgensi Pemanfaatan Rumah Dokter (dokterswoning) sebagai Sumber Pembelajaran Sejarah di Sekolah. In Tim Ahli Cagar Budaya (TACB) Kota Metro (Ed.), Dokterswoning: Sejarah Rumah Dokter Kota Metro (pp. 55-69). AURA Publisher.

9. Amboro, K., \& Bambang, S. (2020). Sekilas Sejarah Rumah Dokter Metro. In Tim Ahli Cagar Budaya (TACB) Kota Metro (Ed.), Dokterswoning: Sejarah Rumah Dokter Kota Metro (pp. 20-28). AURA Publisher.

10. Amboro, K., Syahidah, F., Hartati, U., \& Kuswono, K. (2018). Album Metro Tempo Dulu Era Kolonisasi 1932-1940an. Dinas Perpustakaan dan Kearsipan Kota Metro.

11. Asyhar, R. (2011). Kreatif Mengembangkan Media Pembelajaran. Gaung Persada.

12. Barton, K. C., \& Levstik, L. S. (2008). Teaching History for the Common Good. Lawrence Erlbaum Associates Publishers.

13. Booth, A. (2003). Teaching History at University; Enhancing Learning and Understanding. Routledge.

14. Clark, P., \& Levesque, S. (2018). Historical Thinking: Definitions and Educational Applications. In S. A. Metzger \& L. M. Harris (Eds.), The Willey International Handbook of History Teaching and Learning (pp. 119-148). Willey-Blackwell.

15. Ernasari, E., \& Amboro, K. (2017). Pengaruh Media Pembelajaran Audio Visual Berbasis Windows Movie Maker Terhadap Kemampuan Menganalisis Sejarah Siswa Kelas X Ipa Semester Genap Di Sma Muhammadiyah 1 Metro Tahun Pelajaran 2016/2017. Historia, 5(1), 77. https://doi.org/10.24127/hj.v5i1.734
16. Fadli, M. R., Sudrajat, A., Zulkarnain, Z., Aman, A., Setiawan, R., \& Amboro, K. (2020). The Effectiveness of E-Module Learning History Inquiry Model to Grow Student Historical Thinking Skills Material Event Proclamation of Independence. International Journal of Advanced Science and Technology, 29(08), 1288-1295. http://sersc.org/journals/index.php/IJAST/ar ticle/view/20146

17. Hartati, U. (2016). Museum Lampung sebagai Media Pembelajaran Sejarah. Historia: Jurnal Program Studi Pendidikan Sejarah, 4(1), 1-10. https://ojs.fkip.ummetro.ac.id/index.php/sej arah/article/viewFile/386/336

18. Kuswono, K., Hartati, U., Amboro, K., Mujiyati, N., Immawati, F. L., Tantri, A. D., \& Wijaya, A. R. (2020). Metro Tempo Dulu: Sejarah Kota Metro Era Kolonisasi 1935-1942 (B. Hidayat \& U. Hartati (eds.); 1st ed.). Laduny Alifatama.

19. Kyvig, D. E., \& Marty, M. A. (2010). Nearby History: Exploring The Past Around You (Third Ed.). Altamira Press.

20. Levesque, S. (2008). Thinking Historically: Educating Students for the Twenty-First Century. University of Toronto Press.

21. Rafika, A. S., \& Amboro, K. (2018). Pengembangan Desain Media Pembelajaran Sejarah Movie Maker Berbasis Visualisasi Situs Megalitik Pugung Raharjo Lampung Timur. SWARNADWIPA: Jurnal Kajian Sejarah, Sosial, Budaya, Dan Pembeajarannya, 2(2), 99-108. http://ojs.ummetro.ac.id/index.php/swarnad wipa/article/view/880

22. Ratmanto, A. (2018). Beyond The Historiography: Film Dokumenter Sejarah Sebagai Alternatif Historiografi di Indonesia. SASDAYA: Gadjah Mada Journal of Humanities, 2(2), 405. https://doi.org/10.22146/sasdayajournal.364 52

23. Rikarno, R. (2015). Film Dokumenter sebagai Sumber Belajar Siswa. Ekspresi Seni, $17(1)$. https://doi.org/10.26887/ekse.v17i1.71

24. Samat, B. L. P. (2021). Sejarah sebagai Identitas Bangsa (pp. 1-2). https://doi.org/10.31219/osf.io/a37uy

25. Sugiyono. (2015). Metode dan Penelitian Pengembangan. Alfabeta.

26. Susanto, H., Irmawati, I., Akmal, H., \& Abbas, E. W. (2021). Media Film 
Elis Setiawati et.al. Development of historical learning media based on documentary film to strengthen student's understanding of local history.

Dokumenter dan Pengaruhnya Terhadap Keterampilan Berpikir Kritis Siswa. Historia: Jurnal Program Studi Pendidikan Sejarah, 9(1). https://doi.org/http://dx.doi.org/10.24127/hj. v9i1.2980

27. Utami, C. D. (2010). Film Dokumenter sebagai Media Pelestari Tradisi. Acintya, 2(1). https://doi.org/https://doi.org/10.33153/acy. v2i1.93

How to cite this article: Setiawati E, Hidayat B, Hartati $U$ et.al. Development of historical learning media based on documentary film to strengthen student's understanding of local history. International Journal of Research and Review. 2021; 8(5): 177-186. DOI: https://doi. org/10.52403/ijrr.20210525 